\title{
Effects of Some Weather Parameters on Oil Palm Production in the Peninsular Malaysia
}

\author{
Abubakar Ahmed 1,*, Mohd Yusoff Bin Ishak ${ }^{2}$, Mohd Kamal Uddin ${ }^{3}$, Mohd Yusoff Abd Samad ${ }^{4}$, Suleiman \\ Mukhtar ${ }^{4}$ and Samir Shehu Danhassan ${ }^{5}$
}

\begin{abstract}
${ }^{1}$ Faculty of Forestry and Environment, Universiti Putra Malaysia, 43400 Serdang, Selangor, Malaysia, Email: abubakar8550483@gmail.com

${ }^{2}$ Faculty of Forestry and Environment, Universiti Putra Malaysia, 43400 Serdang, Selangor, Malaysia, Email: m yusoff@upm.edu.my

${ }^{3}$ Faculty of Agriculture University Putra Malaysia, 43400 Serdang, Selangor, Malaysia, Email: myusoffas@upm.edu.my

${ }^{4}$ Faculty of Agriculture University Putra Malaysia, 43400 Serdang, Selangor, Malaysia, Email: mkuddin@upm.edu.my

${ }^{5}$ Department of Geography, Federal University Gashua, Nigeria, Email: smukhtar27.sm@gmail.com

${ }^{6}$ Department of Geography, Jodhpur National University, India, Email: samirshehudanhassan@gmail.com

* Correspondence: e-mail: abubakar8550483@gmail.com; Tel.: +601120755790
\end{abstract}

\begin{abstract}
The effect of some weather parameters (rainfall and temperature) on the production of oil palm in Peninsular Malaysia was investigated. Data were analysed using the Statistical Package for Social Sciences (SPSS 20.0 version), with descriptive statistics, time series analysis, and multiple linear regression (MLR) carried out. SPSS and Microsoft Excel 2010 were used to analyse the results. The MLR model determined the strength of the relationship between oil palm yield (dependent variable) and the changing variables of temperature and rainfall (independent variables). The regression output returned three components; regression coefficients, regression statistics and ANOVA. The findings of the study revealed medium to high rainfall variability at the rate of 0.0008 . This implies that rainfall is increasing over time with variations in its amount and intensity. As rainfall increases oil palm FFB production is predicted to increase at a slow rate of 0.0009 . The estimation of average annual temperature indicated an increase of $5.6^{\circ} \mathrm{C}$ at the rate of $0.0357^{\circ} \mathrm{C}$ per year with a temperature maximum of $32.01^{\circ} \mathrm{C}$ and minimum of $25.45^{\circ} \mathrm{C}$. The result also revealed an increase in oil palm yield at the rate of 0.2581 per year with a mean value of 176247.6. Overall, there is a significant difference in the impact of rainfall and temperature on oil palm yield. This signifies that rainfall has a significant impact on oil palm yield (FFB) compared to temperature.
\end{abstract}

Keywords: Rainfall; Temperature; oil palm Malaysia

\section{Introduction}

Elaeis guineensis or oil palm is the most widely used palm oil species, originating from West Africa [1,2,3,4,5]. It was first introduced to South-east Asia when planted at the Bogor Botanical Garden, Indonesia, in 1848 [3] and first planted in Malaysia as an ornamental plant in 1871 [6]. The first commercial plantation was in 1917 at Tennamaram estate in Selangor, Malaysia [4]. The crop is characterised by its high output turnover, being easy and simple to establish, and is a low cost and highly efficient oil crop [1,7]. Oil palm is now widely cultivated in various tropical countries covering more than 18.1 million hectares in over 43 countries [1]. Indonesia and Malaysia are the major players in oil palm cultivation and produce around $85 \%$ of the global palm oil $[1,8]$. Among the major countries in oil palm production are Indonesia, 
Malaysia, Nigeria, Democratic Republic of the Congo, the Ivory Coast, Brazil, Colombia, Costa Rica, and Ecuador [1,2]. Oil palm thrives in humid climates where rain usually falls at nights and the days brighter with abundant sunshine of minimum 16 or $17 \mathrm{MJ}$ $\mathrm{m}^{-1} \mathrm{~d}^{-}$, with rainfall amounting to $2000 \mathrm{~mm}$ spread equally over the course of the year $[9,10]$. For maximum fresh fruit bunch production, a maximum temperature range of $29-33^{\circ} \mathrm{C}$ and a minimum temperature range of $22-24^{\circ} \mathrm{C}$ is required [2,11]. Relative humidity should be greater than $85 \%$ [10]. Oil palm thrives in a variety of soil conditions, with $\mathrm{pH} 4-8$ and abundant moisture [5]. Oil palm does not thrive well in a competing environment with other plants and areas where there is constant flooding; the plant requires open spaces [2,5]. Oil palm cultivation is vulnerable to the effect of some weather parameters especially temperature and rainfall [12].

The distribution of rainfall affects the growth and development of palm trees, which in turn affects palm oil production. Excessive rainfall also harms the fresh fruit bunch (FFB), reduces the plantation road/path quality, stifles harvest activity, and causes flooding [4]. The yield of oil palm is constrained by the duration of the yearly dry season, so countries that have consistent high rainfall all year round, such as parts of Southeast Asia, have particularly high yields [12]. Soil moisture availability which is determined by the amount of rainfall received and irrigation in some cases is by far the most crucial component in determining the FFB yield of oil palm. Scarcity of moisture in oil palm plantation leads to retarded growth, decline in yield output and tendency of fire incidences, causing mass destruction of the palm trees, polluting and degrading the air quality $[12,13,14]$.

As the impact of climate change is predicted to continue, the danger of floods and droughts is also expected to significantly rise in the 21st century especially in Southeast Asia. Similarly, the impacts of El-Nino and La-Nina will pose risks to oil palm cultivation in Malaysia [15]. Drought in Southeast Asia reduces the production capacity of palm oil by 10-30\% [16]. Drought frequency and severity in Southeast Asia may increase over the next few decades [17,18,19]. Oil palm is vulnerable to lack of rain [1]. Higher temperatures would also lead to a rise in drought conditions, resulting in a devastating loss of FFB yield. Because soil water is lost more quickly as temperatures rise, the effects of dry spells become much more severe [12]. An unfavourable climatic condition such as drought can lessen moisture supply, resulting in water deficiencies which affect FFB formation [20]. Water shortage as a result of drought can reduce the productive capacity of oil palms by decreasing the quantity of the fruits formed as a result of male and female flowering ratios [21,22]. According to past research, a moisture deficit of $100 \mathrm{~mm}$ in a year can reduce yield output by $8-10 \%$ in the year after the drought and 3-4\% in the subsequent years [22,23]. Similarly, [24] observed that a $100 \mathrm{~mm}$ moisture shortage in an oil palm plantation could affect the formation of FFB in the flowering stages causing a $1-10 \%$ yield loss during floral initiation, sex determination and floral abortion. Optimum temperatures and heavy rains are favourable for palm oil production whereas floods and extended periods of drought are unfavourable in most cases.

Heavy rainfall as a result of a La-Nina event affects or delays the harvesting activities of FFB, causing waterlogging, rotten FFB and degrading the quality of CPO. A mean temperature of $\geq 27.83^{\circ} \mathrm{C}$ in the 8 months prior to harvesting has been reported to result in a declining FFB yield [16,25]. Variations between $0.6-1.4^{\circ} \mathrm{C}$ in the temperature range and a $15 \%$ variation in rainfall resulted in an increase in profits for palm oil to a maximum of USD2,453 annually, whereas income earned reduced to USD1,181 in a year, with a 32\% rainfall variation and moderate temperature variation. Malaysia and other oil palm producing nations will be subjected to rising climate ambiguities in the long term [26,27]. Climate change projections indicate that 
the cultivation of oil palm will be hugely affected by climate change, with significant effects for the economy of Malaysia, as well as the palm oil industries. A change in climate status from highly suitable climate to merely suitable climate is projected for Indonesia and Malaysia by 2070 to 2100 [26]. Equally, there will be a more noticeable significant decrease in climatic suitability for oil palm cultivation in the Peninsular Malaysia. A marginal decrease is projected to occur between 2030-2070 and dramatic decrease in 2100 [26,27].

The variations in rainfall over the course of a year in Malaysia is usually influenced heavily by the interannual variation of tropical Pacific sea-surface temperature (SST) anomalies, especially the El-Nino/Southern Oscillation (ENSO) [10]. The El-Nino-Southern Oscillation is a coupled ocean-atmosphere interaction phenomenon that happens in the Pacific Ocean around the equator and is among the most visible drivers of seasonal to interannual global and regional variabilities in climate $[28,29,30]$. The climatic characteristics of the environment have a large influence on oil palm growth and yield. Extreme weather events such as El Nino or La Nina have no direct or immediate impact on oil palm. Instead, they exert their influence on the trees during the initial stages of development, such as frond production, sex ratio, floral abortion scale, the degree of survival of flowers after anthesis, and the weight of fruit bunches [30,31]. Therefore, understanding the impact of rainfall and temperature variability on oil palm production in the Malaysian palm oil industry is critical for designing innovative cultivation practices and ensuring global food security. First, the study will describe the interannual variations and fluctuations in the FFB yield. and the influence of weather variables (rainfall and temperature) on oil palm cultivation.

\section{Materials and Methods}

\section{The study area}

Peninsular Malaysia is the region of Malaysia that includes the Malay Peninsula and its surrounding islands and geographically located $3.9743^{\circ} \mathrm{N}, 102.4381^{\circ} \mathrm{E}$ of the Greenwich Meridian. Its total area is $132,265 \mathrm{~km}^{2}$. Peninsular Malaysia shares borders with Thailand in the northeast and Singapore to the south, and is flanked by the Strait of Malacca in the west and South China Sea in the east. Peninsular Malaysia experiences high temperatures and humidity, as well as heavy rainfall all through the year. The weather and climate of Peninsular Malaysia is usually controlled by the northeast and southwest monsoons. The peninsula's climate is characterised by four seasons; the northeast monsoon usually from the months of November-March, the initial intermonsoonal season usually between March-May, the southwest monsoon usually starting from May to October, as well as the second inter-monsoonal period starting in October and ending in November. 


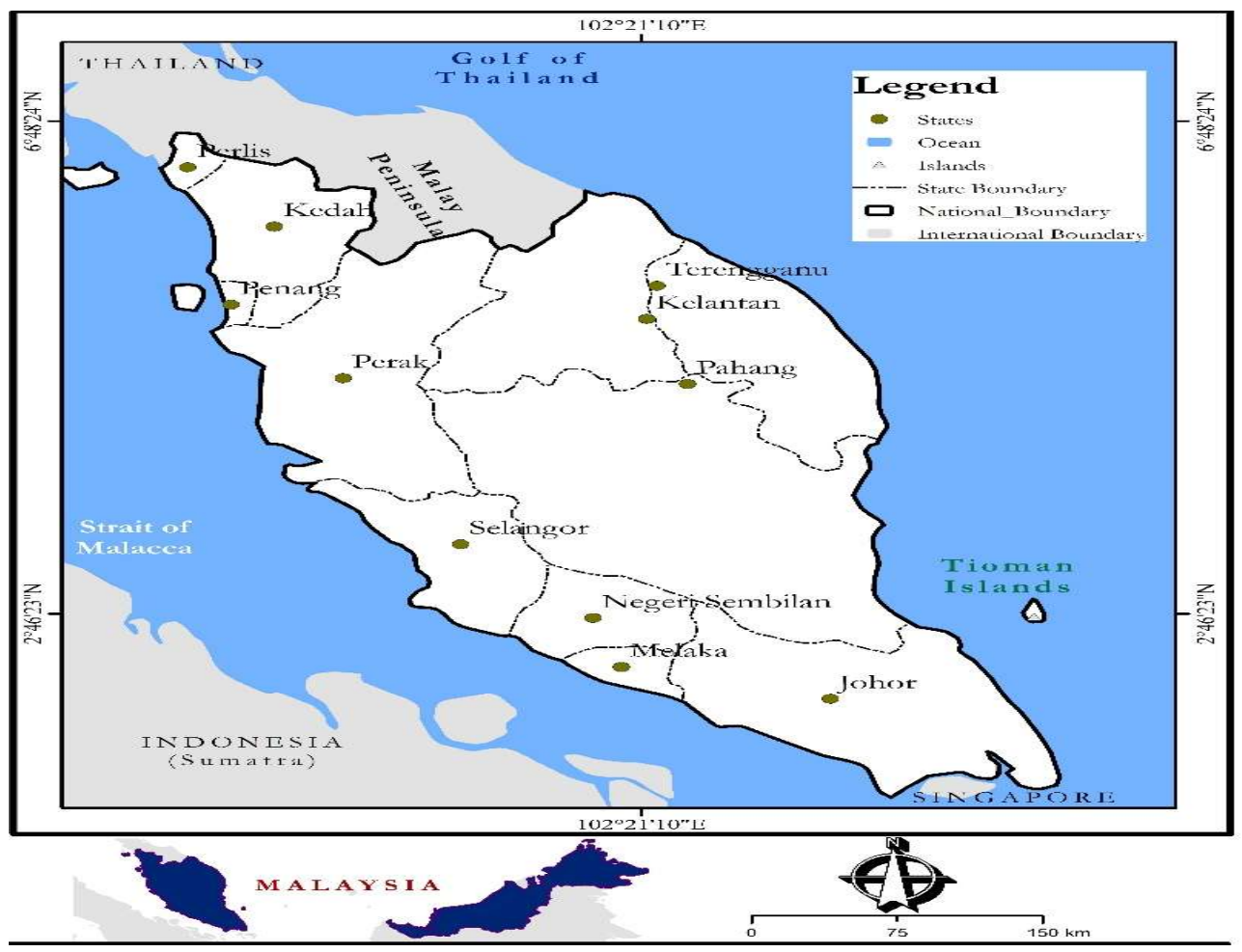

Figure 1. Peninsular Malaysia.

\section{Methods}

Secondary data was used for the purpose of this study. Data on oil palm yield in Malaysia between 1975-2020 was obtained from the Malaysian Palm Oil Board (MPOB). Climate historical data, particularly average annual temperature and rainfall were also downloaded from the climate-knowledge portal of the World Bank, National Hydraulic Research Institute of Malaysia (NAHRIM) and National Oceanic \& Atmospheric Administration (NOAA) in April, 2021. The oil palm yield, rainfall and temperature data were transformed to a common base (log 10) using Minitab software. This was done because the yield of crops is measured in tonnes per hectare (hg/ha) and rainfall in millimetres $(\mathrm{mm})$ whereas temperature is in degree Celsius. The analysis of data used the Statistical Package for Social Sciences (SPSS 20.0 version) specifically using descriptive statistics, time series analysis and multiple linear regression (MLR). Graphs were produced with Microsoft Excel 2010 to summarise the results.

The MLR was used to gauge the relationship strength between oil palm yields (dependent variable), normally signified by ' $Y$ ' and other changing variables (temperature and rainfall) referred to as independent variables (Equation 1) as used by [32] and [33]. The regression output returns three components: regression coefficients, regression statistics and ANOVA tables. The regression coefficients give information about the coefficients in the MLR Model. They include (1) estimates found using the least-squares method; (2) the standard deviation of the least-squares estimates; (3) the $\mathrm{t}$-statistic for the null hypothesis that the coefficient is equal to zero, versus the alternative hypothesis that it is different from zero; (4) the P-value for the t-test; as well as (5) the lower and upper $95 \%$ that define the confidence interval for the coefficients. Meanwhile, the regression statistics table shows the coefficient of multiple determination $\left(R^{2}\right)$ which is defined in terms of sums of squares (Equation 2), and shows how strong the correlation is held between the independent and the dependent variables. $\mathrm{R}^{2}$ will be large (thus, its value is near 1); and vice versa when the regression 
equation fits the data well. The estimate's standard error measures the variability of predictions in a regression. The quantity $\mathrm{R}$ or linear correlation coefficient, measures the strength and direction of relationship between the variables. The ANOVA table evaluates the regression equation by assessing the statistical significance of the regression sum of square.

Thus, trend lines were drawn to show the rainfall, temperature and oil palm yield patterns in the area of study. Linear trend line equations were fitted to show the magnitude of change in these variables

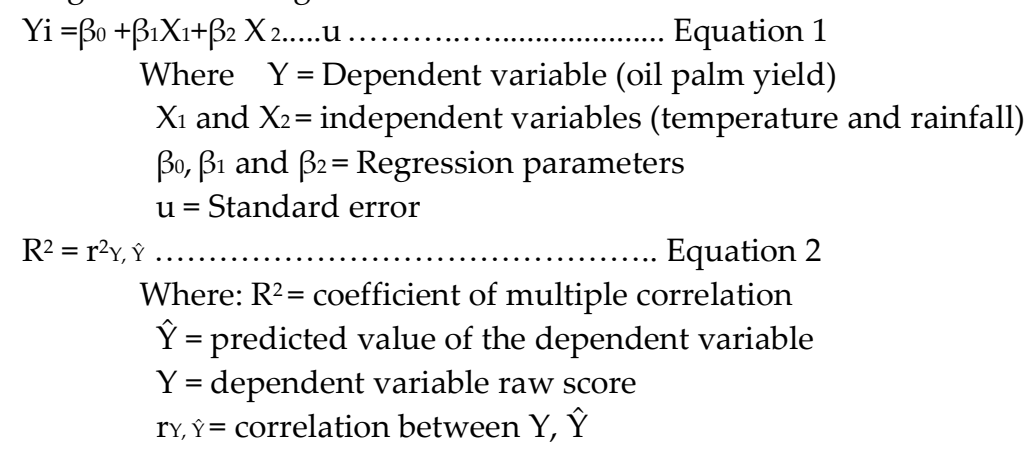

\section{Results and Discussion}

Statistical Characteristics of Rainfall, Temperature and Oil Palm Yield in Peninsular Malaysia

The results of the statistical analysis of annual rainfall, temperature and yield of oil palm in Peninsular Malaysia between the periods of 1991-2019 clearly shows that an annual mean rainfall of $243.7 \mathrm{~mm}$ with a standard deviation of 54.5 , minimum of $156.3 \mathrm{~mm}$, and a maximum of $311.04 \mathrm{~mm}$ were recorded having a range of 286.8 . This depicts a high difference in the highest and lowest amount of rainfall in the area. In addition, it shows that the changes in rainfall was at the rate of 0.0153 (Table 1). For optimum yield, oil palm requires about $1,500 \mathrm{~mm}-2000 \mathrm{~mm}$ of rainfall per year corresponding to around $167 \mathrm{~mm} /$ month with an absence of dry season $[9,10,11,12$, 30].

Table 1. Variation in Rainfall, Temperature and Oil Palm Yield

\begin{tabular}{|c|c|c|c|}
\hline & Mean rainfall & Mean Temp. (yearly) & Value (oil Palm Yield) \\
\hline Mean & 243.6817 & 26.1169 & 176247.6 \\
\hline Standard Error & 10.12254 & 0.233749 & 2908.715 \\
\hline Median & 258.1558 & 25.78 & 175629 \\
\hline Standard Deviation & 54.51154 & 1.258778 & 15663.91 \\
\hline Sample Variance & 2971.508 & 1.584522 & $2.45 \mathrm{E}+08$ \\
\hline Range & 286.8823 & 6.56 & 60974 \\
\hline Minimum & 156.30 & 25.45 & 142425 \\
\hline Maximum & 311.0423 & 32.01 & 203399 \\
\hline Sum & 7066.769 & 757.39 & 5111180 \\
\hline Count & 29 & 29 & 29 \\
\hline $\begin{array}{l}\text { Confidence Level } \\
(95.0 \%)\end{array}$ & 20.73508 & 0.478814 & 5958.232 \\
\hline
\end{tabular}

Source: Author's Analysis (2021)

The estimation of average annual temperature in Peninsular Malaysia for the period $1991-2019$ indicates an increase of $5.6^{\circ} \mathrm{C}$ at the rate of $0.0357^{\circ} \mathrm{C}$ per year with a temperature maximum of $32.01^{\circ} \mathrm{C}$ and minimum of $25.45^{\circ} \mathrm{C}$. However, the mean minimum temperature shows to be $26.11^{\circ} \mathrm{C}$ with standard deviation of 1.26 . The results 
also reveal an increase of oil palm yield in the study area at the rate of 0.2581 per year with a mean value of 176247.6 recorded (Table 1$)$. The average maximum temperature ranges from 29 to $33^{\circ} \mathrm{C}$ and a minimum temperature of 22 to $240^{\circ} \mathrm{C}$ promotes maximum FFB production $[2,10,11,30]$. The plant requires constant sunlight of at least 5 hours in a day for an optimum yield [10,12,30].

\section{Rainfall and temperature trend in Peninsular Malaysia.}

Rainfall trend

The rainfall trend in Peninsular Malaysia shows a strong variability. For example, 1992 and 2019 recorded the lowest rainfall of $209.18 \mathrm{~mm}$ and $156.3 \mathrm{~mm}$, respectively, while 2008 recorded the highest amount of rainfall at $320 \mathrm{~mm}$. The $\mathrm{Y}$ value stands at 0.0008 . This implies that rainfall in the study area was increasing over time with variations in its amount and perhaps intensity. This indicates an irregular pattern within the period of the study. A trend of increased rainfall over Peninsular Malaysia favours optimum oil palm FFB production [11,12,30,34,35]. However, as the global climate is changing and getting warmer resulting in irregular and uncertain rainfall patterns, storm surges frequency, and prolonged droughts in some places around the globe [36].

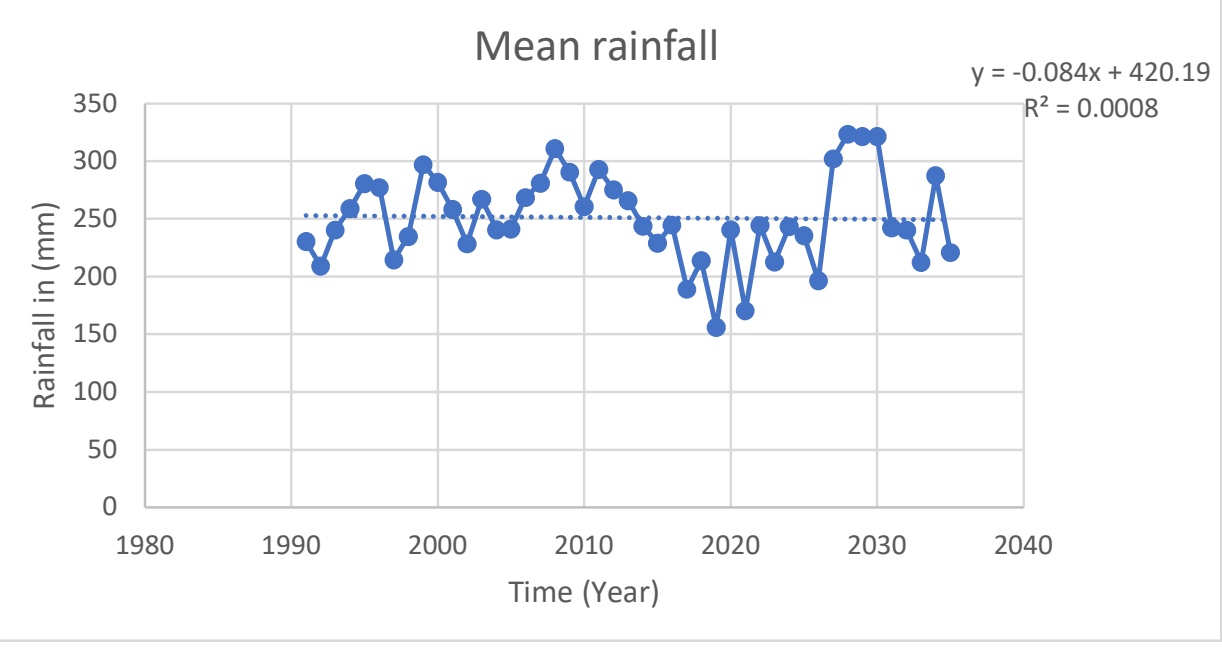

Figure 2. Annual Mean Rainfall of Peninsular Malaysia 1991-2035. Source: Author's analysis

The study observed an irregular increase in rainfall in terms of intensity and temporal distribution in the study area. Noticeably, there was an increase in rainfall between 2013 and 2017 and a decrease between 2017 and 2019 (Figure 2). This concurs with the study of [37], which demonstrated that, besides the northern region of the south-west zone, all regions in Peninsular Malaysia have a significant uptrend with at least a $90 \%$ level of confidence in January. It has been noted that the northeast monsoon (NEM) brings overwhelming rain to Peninsular Malaysia in comparison with the southwest monsoon (SWM). The southwest and western coastal areas experience a greater range of variation in rainfall under the NEM, and to a lesser degree during the SWM.

Other studies in West Malaysia found increasing trends in annual rainfall as well as the intensity of rainy days at various meteorological stations during the NEM, leading to an increased pattern in annual rainfall [37,38,39,40]. Studies by [41] and [42] have shown that as the earth's surface warms, moisture evaporates from the surfaces such as oceans, lakes and soils. Climatic models also tend to agree that when precipitation does occur, it will become more intense almost everywhere. 
In addition, the figure 2 above reveals that rainfall in Peninsular Malaysia from 2020 to 2035 is predicted to show an increasingly irregular pattern. This is in conformity

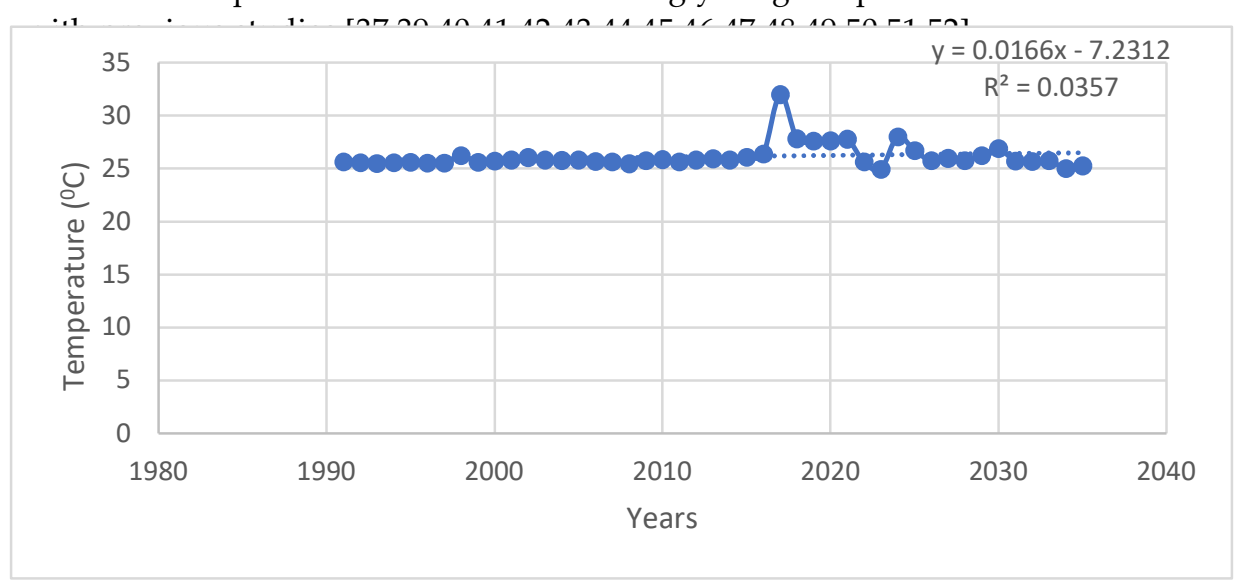

Figure 3. Annual Mean Temperature for Peninsular Malaysia 1991-2035. Source: Author's analysis

Figure 3 shows the mean annual temperature for Peninsular Malaysia from 1991 to 2035 . The figure shows that the maximum mean temperature recorded was in 2017 at $32.01^{\circ} \mathrm{C}$ while the lowest mean temperature recorded was in 2008 at $25.45^{\circ} \mathrm{C}$. The study area experienced a sharp decrease in annual average temperatures from 1991 to 1997 . In 1998 , the annual average temperature rose to $26.24^{\circ} \mathrm{C}$ and further dropped to $25.6^{\circ} \mathrm{C}$ and increasingly continued fluctuating. Generally, the daily average temperature in the study area shows an increasing trend with a positive $\mathrm{Y}$ value of 0.0357 (Figure 3). Similarly, several studies have confirmed the trend of rising temperatures in Malaysia [39,40].

This is a clear indication that temperature (minimum, maximum and average) is on the increase in Peninsular Malaysia. When temperature rises by $1-4^{\circ} \mathrm{C}$ oil palm production is expected to decline by $10-40 \%$ in Malaysia [35]. The general temperature increase in the study area affirms the assertion of the [53] that temperature is expected to increase over time as a result of ozone depletion, arising from anthropogenic activities, which increases the concentration of greenhouses gases (GHGs) in the environment. The study is in conformity with the findings of [54] which claimed that the mean surface temperature of the Earth rose by around $0.6^{\circ} \mathrm{C} \pm 0.2^{\circ} \mathrm{C}$ during the $21 \mathrm{st}$ century. The authors went on to say that it is warmer today than at any other time in the last 1000 years all over the world. Weather extremes are becoming more common around the world and are far more probable to continue in the future. Temperatures are deemed to be extreme due to climate change and the rising trend would be maintained sporadically as discovered in this study area. 


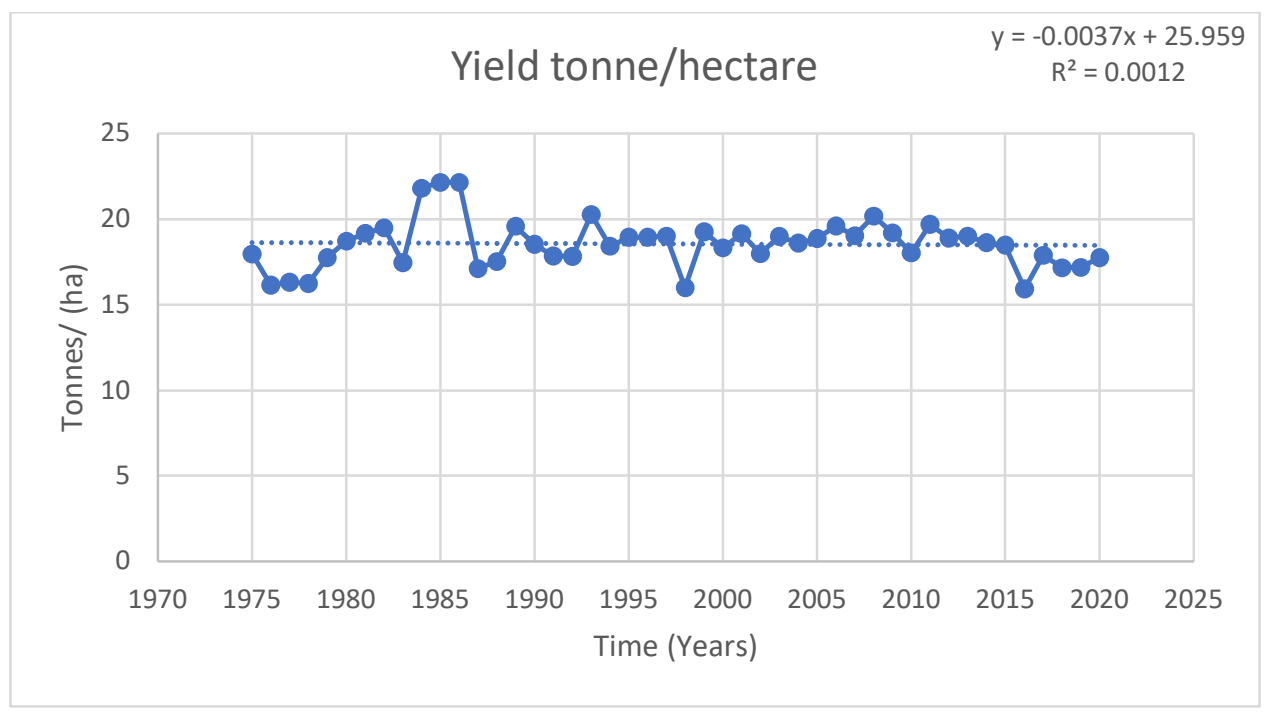

Figure 4. Trend of Oil Palm Yield in Peninsular Malaysia from 1975 to 2020. Source: Author's analysis

The yield of oil palm fluctuated from 1975 to 1983 . Yield in 1983 was about 17.45 tonnes per hectare and sharply increased to 21.80 and 22.15 in 1984 and 1986, respectively, before drastically declining to 17.10 tonnes per hectare in 1987 . The lowest yields of oil palm recorded in the study area were in 1998 and 2016, while the highest were recorded in 1993 and 2008 (Figure 4). The decline of FFB in 1998 and 2016 was the result of a strong El-Nino. When El-Nino develops in the Pacific Ocean, rainfall in Peninsular Malaysia decreases while air temperature rises, causing palm trees to experience high levels of water stress. Because of this, the annual production of FFB is less than in a normal year, as a result of water stress during the southwest monsoon having a significant effect on annual FFB yields [10]. La-Nina, in contrast, creates a favourable setting for palm trees and higher FFB production by lowering the risk of water stress [10,55]. Generally, the trend in oil palm yield in the study area is increasing with a positive $Y$ value of 0.2581 (Figure 4).

\section{The Relationship between Rainfall, Temperature and Oil Palm Yield Multiple regression model}

Table 2. The relationship between rainfall, temperature and oil palm yield

\begin{tabular}{ll}
\hline Regression Statistics & \\
\hline Multiple R & 0.381065 \\
\hline R Square & 0.14521 \\
\hline Adjusted R Square & 0.079457 \\
\hline Standard Error & 15028.72 \\
\hline Observations & 29 \\
\hline
\end{tabular}

Source: Author's Computation, 2021

Table 2 indicate that there is a significant association between the weather element (rainfall and temperature) and oil palm yield in Peninsular Malaysia. This is shown with an R-value of 0.381 , which is greater than the significant level of 0.05 . However, it has a R-square value of 0.145 that depicts the level of relationship. This 
simply means that among the factors that affect oil palm yield, rainfall and temperature accounts for $14 \%$. Other climatic elements, topographic and sociocultural practices account for the remaining $86 \%$ percentage. These may include relative humidity, wind, sunshine, soil fertility and gradient, nature of tillage and fertiliser application, among others. This agrees with the study of [56] in Peninsular Malaysia which confirmed that rainfall at 18 months before harvesting showed a significant relationship with oil palm yield. This is because high rainfall is related to the development of female inflorescence and results in bumper harvests of FFB. Moisture stress is known to cause fewer female flowers, which also reduces FFB formation.

\section{Multiple Regression Line Fit Plot}

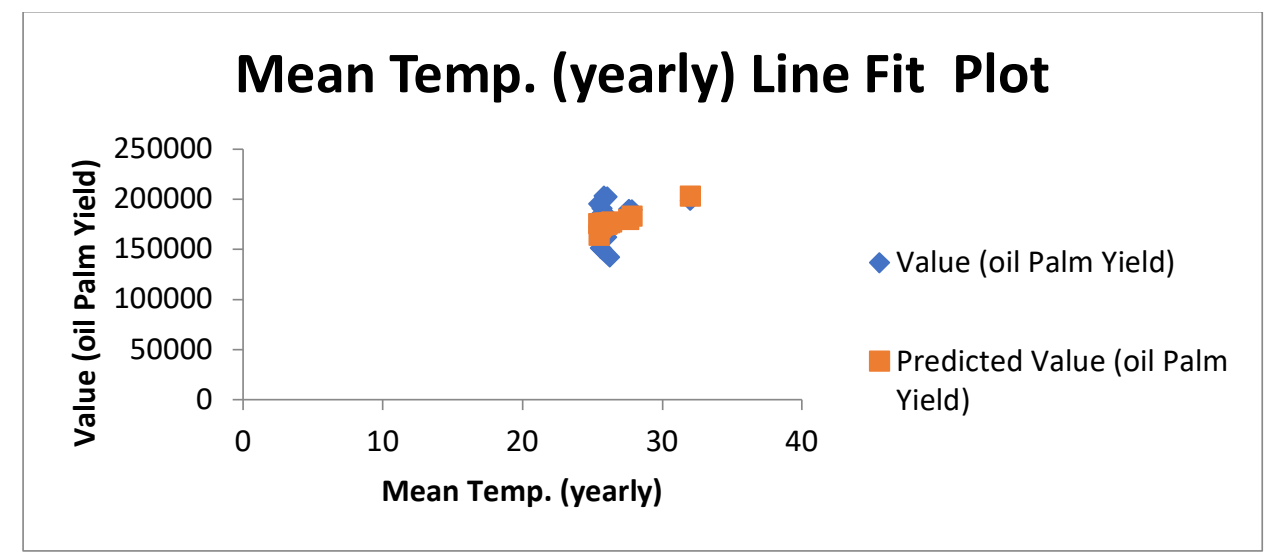

Figure 5. Average annual temperature-line fit plot. Source: Author's computation 2021

The relationship between temperature and oil palm yield indicates that as the temperature increases within a certain limit, the oil palm yield is predicted to increase (Figure 5). This seems to be due to the fact that the temperature requirements for oil palm are straightforward. The best temperatures are those with the fewest fluctuations. Growth is halted below $18^{\circ} \mathrm{C}$. The ideal daily temperature is $27-28^{\circ} \mathrm{C}$, with average monthly values ranging from $30-32^{\circ} \mathrm{C}$ to $21-24^{\circ} \mathrm{C}$. The average minimum temperature during the coolest month should be greater than $18^{\circ} \mathrm{C}$. Growth of seedlings is halted at temperatures below $15^{\circ} \mathrm{C}$, although temperatures between $28-32^{\circ} \mathrm{C}$ favour stem growth, FFB ripening, flower development, frond development and enhance the rate of metabolic activities [20,57]. Oil palm produces the highest yields in areas with a maximum average temperature of $29-33^{\circ} \mathrm{C}$ and a minimum average temperature of $22-$ $24^{\circ} \mathrm{C}[30]$. 


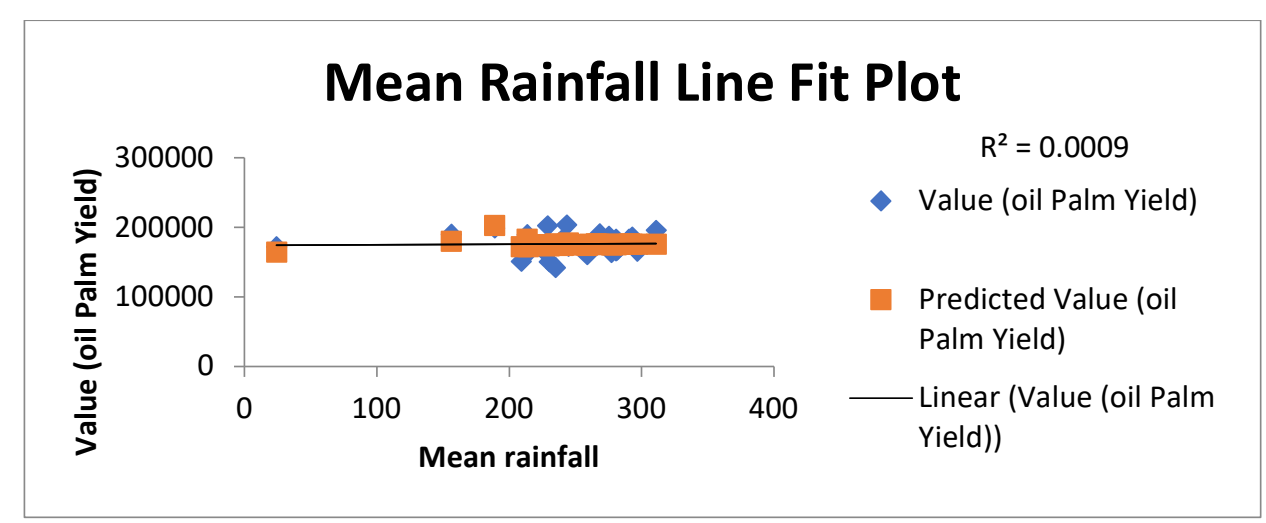

Figure 6. Average Annual Rainfall (mm) Line Fit Plot. Source: Author's computation (2021).

The relationship of oil palm yields as predicted in the model shows that as rainfall increases, the oil palm yield will increase but at a slow rate of 0.0009 (Figure 6). This is due to the fact that oil palm needs a rainfall of $150 \mathrm{~mm}$ per month, and a dry season of not more than 2-3 months. On average, 1,800-2,500 $\mathrm{mm}$ of annual rainfall is considered ideal for oil palm production in Malaysia. Annual rainfall exceeding 2,500 $\mathrm{mm}$ is deemed unfavourable because it disrupts solar radiation and affects the rate of photosynthesis in the palm trees. It has been observed that 2,000 $\mathrm{mm}$ of rain per year produces high FFB yields in western Malaysia.

\section{Test of Goodness of Fit of the Data}

Table 3. Analysis of Variance

\begin{tabular}{lrrrrr}
\hline & Df & \multicolumn{1}{c}{ SS } & MS & \multicolumn{1}{c}{ F } & \multicolumn{1}{c}{ Significance F } \\
\hline Regression & 2 & $9.98 \mathrm{E}+08$ & $4.99 \mathrm{E}$ & 2.208422 & 0.130068 \\
\hline Residual & 26 & $5.87 \mathrm{E}+09$ & $2.26 \mathrm{E}$ & & \\
\hline Total & 28 & $6.87 \mathrm{E}+09$ & & & \\
\hline
\end{tabular}

Source: Author's computation (2021).

The analysis of variance was employed to test the statistical significance of rainfall and temperature as indicators for oil palm yield. There is a significant variation in the effect of the independent variables (rainfall and temperature) on the dependent variable (oil palm yield). This means one of the independent variables has a stronger relationship than the other. This was validated by the F-statistics (2.21) being greater than the p-value (0.13) (Table 3).

\section{Regression coefficients}

The regression coefficient shows the relationship in the multiple regression model between each independent variable (rainfall and temperature) and dependent variable (oil palm yield).

Table 5. Regression Coefficients

\begin{tabular}{lrrrrrr}
\hline & Coefficients & Standard Error & \multicolumn{1}{c}{ t Stat } & P-value & Lower 95\% & Upper 95\% \\
\hline Intercept & 37399.24 & 66548.02 & 0.561989 & 0.578937 & -99392.2 & 174190.7 \\
$\begin{array}{l}\text { Mean rainfall } \\
\begin{array}{l}\text { Mean Temp. } \\
\text { (yearly) }\end{array}\end{array}$ & 41.18689 & 54.3635 & 0.75762 & 0.455491 & -70.5589 & 152.9327 \\
\hline
\end{tabular}

Source: Author's computation (2021) 
Table 5 shows that mean rainfall has a relationship with oil palm yield with an Rvalue of 41.1 . This is statistically significant as the p-value $(0.455)$ is higher than 0.05 (significant level). This is not the case for mean temperature, which has an R-value of 4932.13 and a p-value (0.046) that is less than the 0.05 significant level. This simply means that rainfall has a positive correlation with oil palm yield while temperature has no relationship.

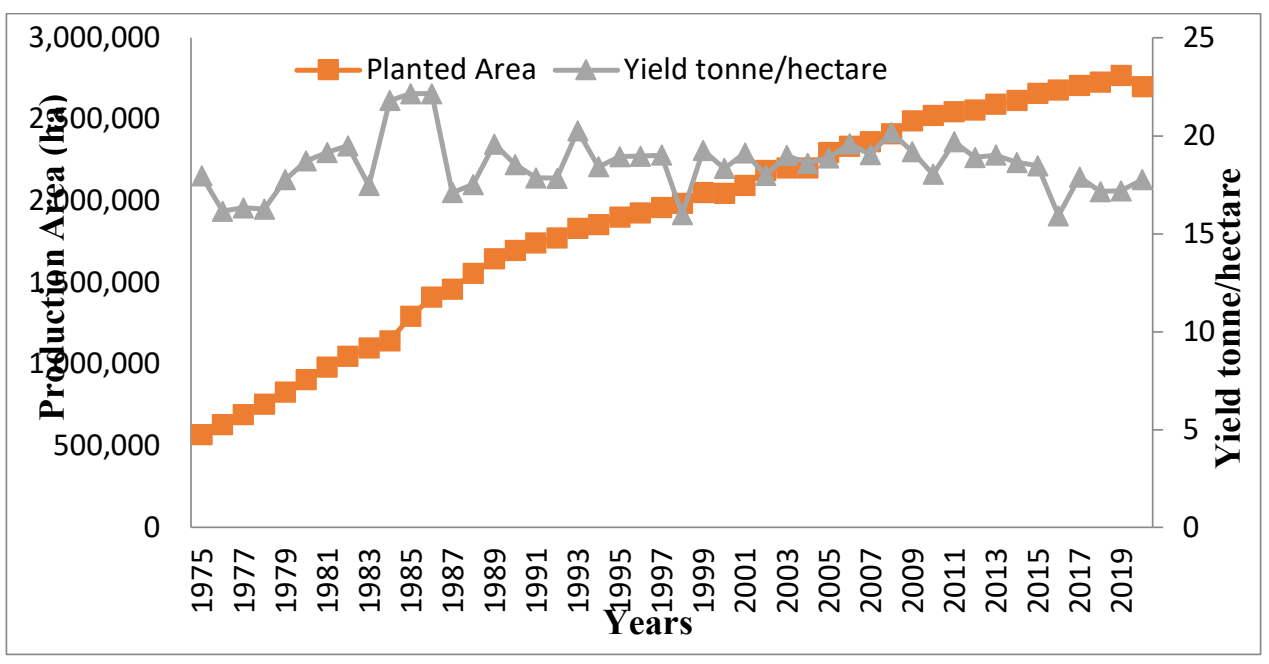

Figure 7. Production area and oil palm yield. Trend of oil palm production and its area

Since 1960, land area cultivated with oil palm has grown rapidly. In Peninsular Malaysia for instance, 568,561 hectares (ha) were cultivated in 1975. In 1985, 1,292,399 ha of palm trees had been planted, and this figure had risen to 2,362,057 ha in 2007. Oil palm has grown to be the leading agricultural commodity in the country. As of 2019, the total planted area was 2,769,003 hectares and slightly declined to 2,700,004 hectares which is attributed to the Covid-19 pandemic (MPOB, 2019) (Figure 7). Cultivation of oil palm vital to Malaysia's economic health, being the second largest exporter of palm oil globally $[4,5,11,16,27,35,58,59]$. The palm oil sector employs a huge workforce, with a combined employee number of 1.16 million individuals in Malaysia, accounting for $40.45 \%$ of agricultural employment [35].

In 1975, a yield of 17.95 tonnes per hectare was recorded in Peninsular Malaysia. The trend of FFB per hectare continues to fluctuate as a result of climatic variability and management practices. The highest yields were recorded in 1984, 1985 and 1986 (Figure 7). However, 15.98 and 15.91 tonnes per hectare were recorded in 1998 and 2016, respectively. These were the result of a strong El-Nino which caused water stress and rising temperatures, thereby a decline in FFB yield. Similarly, yields of 17.16 and 17.17 tonnes per hectare were recorded in 2018 and 2019. This is attributed to the decline in rainfall where $213.71 \mathrm{~mm}$ and $156.3 \mathrm{~mm}$ of rainfall were recorded in 2018 and 2019, respectively. 


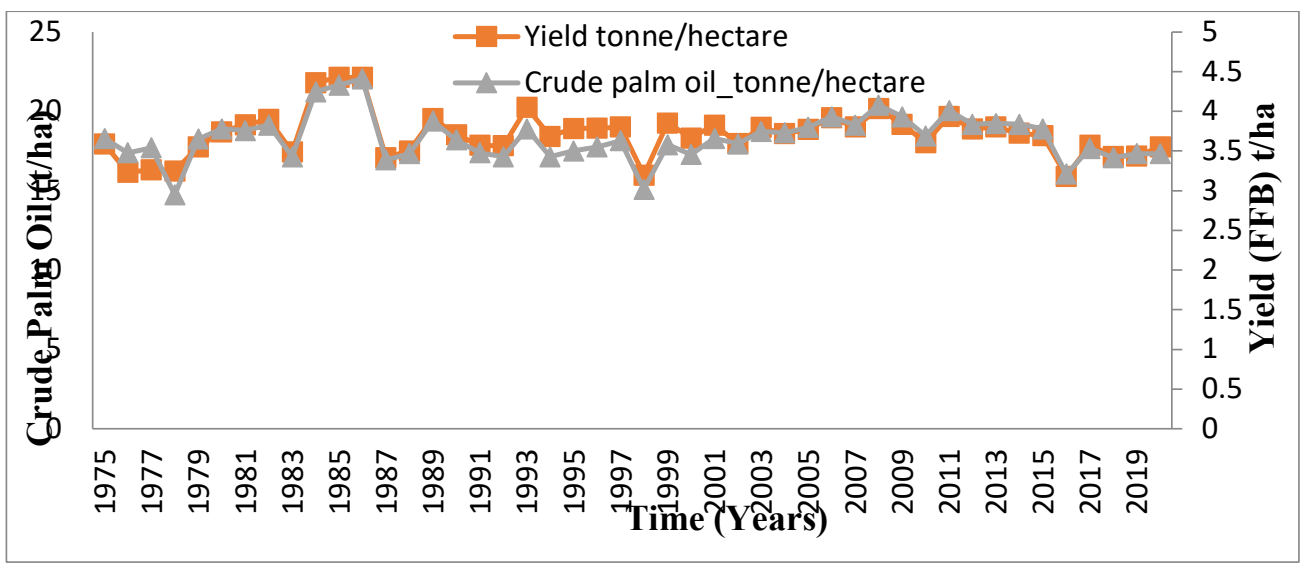

Figure 8. Trend of FFB and Crude Palm Oil Production in Peninsular Malaysia.

The production of crude palm oil (CPO) depends on the quality and quantity of FFB along with industrial processes. For instance, 1984 and 1986 recorded the highest FFB yields at 21.80 and 22.15 tonnes per hectare, respectively. Similarly, CPO production was highest in 1984 and 1986 with 4.25 and 4.41 tonnes per hectare, respectively (Figure 8). The effect of 1998's El-Nino resulted in a decline in FFB yield which also influenced CPO production negatively. FFB production stood at 15.98 tonnes per hectare and CPO production was 3.03 tonnes per hectare in 1998. However, both FFB and CPO production declined to 15.91 tonnes per hectare and 3.21 tonnes per hectare in 2016 (figure 8). This was caused by a strong El-Nino that occurred in 2015/2016. El Nino events in the Pacific Ocean can cause decreased rainfall and increased air temperatures across Malaysia. These changes have the potential to cause severe water stress to the palm trees. In Peninsular Malaysia, CPO production has a distinct annual rhythm, with minimal output usually around January to the month of March and maximum production occurring around the month of August and November. The rhythm is thought to be influenced by photoperiodic responses within a phytomere and is also driven by variations in the environmental factors caused mainly by El-Nino-Southern Oscillation (ENSO) [20]. The decline in CPO production in 2018 was the result of lower quantity of processed FFB. The decline was by $3.2 \%$ to 97.80 million tonnes as a result of the lower FFB productivity i.e. decreased by $4.1 \%$ to 17.16 tonnes per ha in Malaysia as opposed to 17.89 tonnes per ha in 2017. Low demand from palm oil importing countries, especially Vietnam, Egypt, and the EU, diminished palm oil consumption in 2018 by 0.07 million tonnes, or 0.4 percent, to 16.49 million tonnes, down from 16.56 million tonnes in 2017 [60].

Malaysia accounts for over $25.8 \%$ of global palm oil production and is responsible for $34.3 \%$ of the global export of palm oil [61]. Malaysia is now the number two producer of palm oil globally, having been surpassed by Indonesia in 2006. Since 1985, palm oil has surpassed soyabean oil to become the second most consumed oil in the world. Malaysia had a 51\% share of global production in 1999, but that had dropped to $38 \%$ in 2011 [61].

\section{CONCLUSION}

Oil palm production is affected by some elements of weather and climate especially temperature and rainfall. This study shows a significant increasing trend in rainfall, temperature and oil palm yield in Malaysia from 1991 to 2020 at a 95\% confidence level. This finding is in line with the findings by other researchers. The study also shows that rainfall and temperature have a significant relationship with oil palm yield though at a very low rate of $14 \%$. Future research will most likely 
include the delineation of climatic regions using statistical analysis of Malaysia's monthly gridded data set using rainfall variability and temperature indices. It will be useful to further explore the relationship between oil palm yield and other climatic and cultural factors aside from rainfall and temperature. This will give the oil palm farmers insight into the agricultural practices suitable for oil palm production.

\section{Declaration}

Ethics approval and consent to participate

This study neither involved human/animal participation, experiment, nor human data/tissue.

\section{Consent for publication}

This study did not involve children or individual details, but $100 \%$ data usage.

\section{Data availability statement}

All data generated or analysed during the study are included in the published article(s) cited within the text and acknowledged in the reference section.

\section{Competing interest}

All authors declare no competing interest.

\section{Funding}

The study was funded by the Tertiary Education Trust Fund, Nigeria (TETFUND).

\section{Contribution of authors}

Ahmed Abubakar is the corresponding author. He contributed in the sourcing of relevant literature, as well as synthesis, organisation, and drafting of the manuscript.

Dr Mohd Yusoff Ishak, Assoc. Md Kamal Uddin and Assoc. Prof. Mohd Yusoff Abd Samad critically reviewed the manuscript with addition and subtraction where necessary within the manuscript.

Mr. Suleiman Mukhtar and Samir Shehu Danhassan contributed in referencing formatting and similarity index checking.

\section{Acknowledgment}

I wish to acknowledge Tertiary Education Trust Fund (TETFUND) for sponsoring this review research. I am indebted to Dr Mohd Yussof Ishak and Prof Abdullah Ahmad Makmom for their critical review towards this work.

\section{References}

1. Dislich, C.; Keyel, A.C.; Salecker, J.; Kisel, Y.; Meyer, K.M.; Auliya, M.; Barnes, A.D.; Corre, M.D.; Darras, K.; Faust, H.; Hess, B.; Klasen, S.; Knohl, A.; Kreft, H.; Meijide, A.; Nurdiansyah, F.; Otten, F.; Pe, G.; Steinebach, S., ... Wiegand, K. A review of the ecosystem functions in oil palm plantations, using forests as a reference system. Biol. Rev 2017, 49, 1539-1569, $\underline{\text { https://doi.org/10.1111/brv.12295 }}$

2. Corley, R.H.V.;Tinker, P.B. The Oil Palm, 4th Ed.; Corley, R.H.V.; Tinker, P.B.; Eds.; Wiley-Blackwell, Hoboken, New Jersey USA, 2003, pp. 1-562.

3. Nambiappan, B.; Ismail, A.; Hashim, N.; Ismail, N.; Shahari, D.N.; Idris, N.A.N.; Omar, N.; Salleh, K.M.; Hassan, N.A.M.; Kushairi, A. Malaysia: 100 years of resilient palm oil economic performance. J. Oil Palm Res. 2018, 30, 13-25. https://doi.org/10.21894/jopr.2018.0014

4. Ahmed, A.; Mohd, Y.B.I.; Abdullah, A.M. Oil palm in the face of climate change: A review of recommendations. IOP Conference Series: Earth and Environmental Science, 2021 646, 1-10. https://doi.org/10.1088/1755-1315/646/1/012065

5. Paterson, R.R.M.; Sariah, M.; Lima, N. How will climate change affect oil palm fungal diseases? Crop Prot. 2013, 46, 113-120. https:// doi.org/10.1016/j.cropro.2012.12.023 
6. Basiron, Y.; Weng, C.K. The oil palm and its sustainability. J. Oil Palm Res. 2004. 16, 1-10

7. Wahid, M.B.; Abdullah, S.N.A.; Henson, I.E. New directions for a diverse planet. Proceedings of the 4th International Crop Science Congress, Brisbane, Australia. 26 Sep - 1 Oct 2004 Crop Science Society of America, Fitchburg, USA, 2004.

8. MPOB. Malaysian oil palm statistics 2019. 39th Ed.; Malaysian Palm Oil Board. Kajang, Selangor, Malaysia, 2019, pp. 2-205.

9. Basiron, Y. Palm oil production through sustainable plantations. Eur J Lipid Sci Technol. 2007, 109, $289-295$. https://doi.org/10.1002/ejlt.200600223

10. Oettli, P.; Behera, S.K.; Yamagata, T. Climate Based Predictability of Oil Palm Tree Yield in Malaysia. Sci. Rep. $2018,8,1-13$. https://doi.org/10.1038/s41598-018-20298-0

11. Zainal, Z.; Shamsudin, M.N.; Mohamed, Z.A.; Adam, S.U. Economic Impact of Climate Change on the Malaysian Palm Oil Production. Trends Appl Sci Res, 2012 7, 872-880.

12. Fleiss, S.; Hill, J.K.; Mcclean, C.; Lucey, J.M.; Reynolds, G. Potential Impacts of Climate Change on Oil Palm Cultivation: A science-for-policy. 2017, pp. 1-16. http://www.sensorproject.net/wp-content/uploads/2018/01/Climate-change-reportFINAL.pdf. Accessed on 12/05/2021.

13. Bakoumé, C.; Shahbudin, N.; Yacob, S.; Siang, C.S.; Thambi, M.N. Improved method for estimating soil moisture deficit in oil palm (Elaeis guineensis Jacq.) areas with limited climatic data, J. Agr. Sci. 2013, 5, 57-65, https://doi.org/10.5539/jas.v5n8p57.

14. Noojipady, P.; Morton, D.C.; Schroeder, W.; Carlson, K.M.; Huang, C.; Gibbs, H.K.; Burns, D.; Walker, N.F.; Prince, S.D. Managing fire risk during drought: the influence of certification and El 14 Potential impacts of climate change on oil palm cultivation Niño on fire-driven forest conversion for oil palm in Southeast Asia. Earth Syst. Dyn. 2017, 8, 1-23.

15. Christensen, J.H.; Krishna, K.; E. Aldrian, S.I.; Cavalcanti, I.F.A.; Castro, M.; Dong, W.; Goswami, P.; Hall, A.; Kanyanga, J.K.; Kitoh, A.; Kossin, J.; Lau, N.C.; Renwick, J.; Stephenson, D.B.; Xie, S.P.; Zhou, T. Climate Phenomena and their Relevance for Future Regional Climate Change. In: Climate Change: The Physical Science Basis. Contribution of Working Group I to the Fifth Assessment Report of the Intergovernmental Panel on Climate Change Ed.; Stocker, T.F.; Qin, D.; Plattner, G.K.; Tignor, M.; Allen, S.K.; Boschung, J.; Nauels, A.; Xia, Y.; Bex, V.; Midgley, P.M. 2013 Cambridge University Press, Cambridge, United Kingdom and New York, NY, USA. pp. 20-43

16. Paterson, R.R.M.; Lima, N. Climate change affecting oil palm agronomy, and oil palm cultivation increasing climate change, require amelioration. Ecol. Evol, 2018, 8, 452-461. https://doi.org/10.1002/ece3.3610

17. Wen, P.P.; Sidik, M.J. Impacts of rainfall, temperature and recent El Niños on fisheries and agricultural products in the West Coast of Sabah [2000-2010]. Borneo Sci. 2011, 28, 75-85

18. Li, Y.; Ye, W.; Wang, M.; Yan, X. Climate change and drought: a risk assessment of cropyield impacts. Clim. Res. 2009, 39, 31-46.

19. Chotamonsak, C.; Salathé, E.P.; Kreasuwan, J.; Chantara, S.; Siriwitayakorn, K. Projected climate change over Southeast Asia simulated using a WRF regional climate model. Atmos. Sci. Lett, 2011, 12, 213-219

20. Tani et al. Small temperature variations are a key regulator of reproductive growth and assimilate storage in oil palm (Elaeis guineensis), Sci. Rep. 2020, 10, 650. https://www.doi.org/10.1038/s41598-019-57170-8

21. Corley, R.H.V.; Rao, V.; Palat, T.; Praiwan, T. Breeding for drought tolerance in oil palm. J. Oil Palm Res. 2018, 30, 26-35. https://www.doi.org/10.21894/jopr.2017.00011

22. Suharyanti, N.A., Mizuno, K., Sodri, A. The effect of water deficit on inflorescence period at palm oil productivity on peatland. The $1^{\text {st }}$ JESSD Symposium: International Symposium of Earth, Energy, Environmental Science and Sustainable Development, Indonesia, 28 to 30 September, 2020, 17, Avenue du Hoggar, France, 2020

23. Caliman, J.P., Southworth, A. Effect of drought and haze on the performance of oil palm, International Oil Palm Conference, Bali, Indonesia, 23-25 September 1998, PT Smart Corporation, Indonesia, 1998. pp. 1-20.

24. Corley, R.H.V. \& Tinker, P.B.H. The Oil Palm. 5th Ed.; Corley, R.H.V.; Tinker, P.B.; Eds.; Wiley-Blackwell, Hoboken, New Jersey USA, 2015, pp. 1-674 
25. Shanmuganathan, S.; Narayanan, A.; Mohamed, M.; Ibrahim, R; Khalid, H. A hybrid approach to modelling the climate change effects on Malaysia's oil palm yield at the regional scale. Adv Intell Syst Comput 2014, 287, 335-346.

26. Paterson, R.R.M.; Kumar, L.; Taylor, S.; Lima, N. Future climate effects on suitability for growth of oil palms in Malaysia and Indonesia. Sci. Rep. 2015, 5, 1-11. https://doi.org/10.1038/srep14457

27. Paterson, R.R.M.; Kumar, L.; Shabani, F.; Lima, N. World climate suitability projections to 2050 and 2100 for growing oil palm. J. Agric. Sci. 2017, 155, 659-702. https://doi.org/10.1017/S0021859616000605

28. Naylor, R.; Walter, P.F.; Daniel, R.; Wada, N. Using El-Nino/Southern Oscillation Climate Data to Predict Rice Production in Indonesia. Clim. Change. 2001, 50, 255-265.

29. Wolter, K.; Timlin, M.S. El Niño/Southern Oscillation behaviour since 1871 as diagnosed in an extended multivariate ENSO index (MEI.ext), Int. J. Climatol., 2011 31, 1074-1087, https://doi.org/10.1002/joc.2336.

30. Kamil, N.N.; Omar, S.F. Climate change variability and its impacts on the oil palm industry. Oil Palm Indust. Econ. J. 2016, 16, 18-30

31. Verheye W. Growth and production of oil palm. In: Verheye WH, editor. Land use, land cover and soil sciences. Oxford, UK: UNESCO-EOLSS Publishers; 2010, 1-24

32. Ozor, N.; Umunakwe, P.C.; Ani, A.O.; Nnadi, F.N. Perceived Impacts of Climate Change Among Rural Farmers in Imo State, Nigeria: Afr. J. Agric. Res. 2015, 10, 1756-1764.

33. Garba, J.I.; Sawa, B.A.; Shariason, A.A. Awareness of and Adaptation Strategies to Climate Changes Tudun Wada Local Government Area of Kano State; Zaria Geog. 2018, 23, 13 - 21

34. Shanmuganathan, S.; Narayanan, A. Modelling the climate change effects on Malaysia's oil palm yield. 2012 IEEE Symposium on E-Learning, E-Management and E-Services, 2012, 1-6.

35. Sarkar, M.S.K.; Begum, R.A.; Pereira, J.J. Impacts of climate change on oil palm production in Malaysia. Environ. Sci. Pollut. Res. 2020, 27, 9760-9770. https://doi.org/10.1007/s11356-020-07601-1

36. UNISDR. Annual report. United Nations Office for Disaster Risk Reduction (UNISDR) 9-11 Rue de Varembé, 1202 Geneva, Switzerland, 2015. pp. 3-10

37. Wong, C L.; Liew, J.; Yusop, Z.; Ismail, T.; Venneker, R.; Uhlenbrook, S. Rainfall characteristics and regionalization in peninsular malaysia based on a high resolution gridded data set. Water, 2016, 8, 1-16. https://doi.org/10.3390/w8110500

38. Suhaila, J.; Sayang, M.D.; Wan Zawiah, W.Z.; Abdul Aziz, J. Trends in Peninsular Malaysia rainfall data during the Southwest Monsoon and northeast monsoon seasons: 1975-2004. Sains Malays. 2010, 39, 533-542

39. Wong, C. Yusop, Z.; Ismail, T. Trend of Daily Rainfall and Temperature in Peninsular Malaysia Based on Gridded Data Set. Int. J. GEOMATE. 2018, 14, 65-72

40. Tang, K.H.D. Climate change in Malaysia: Trends, contributors, impacts, mitigation and adaptations. Sci. Total Environ. 2019, 650, 1858-1871. https://doi.org/10.1016/j.scitotenv.2018.09.316

41. Zeke, H. Climate Modelling. Explainer: What climate models tell us about future rainfall? Available online: https://www.carbonbrief.org/explainer-what-climate-models-tell-us-about-future-rainfall. (Accessed on 27/04/2021).

42. Climate Central. Pouring it on: How Climate Change Intensifies Heavy Rain Events. Available on: https://www.climatecentral.org/news/report-pouring-it-on-climate-change-intensifies-heavy-rain-events\#: :text=Human\%2Dcaused\%20climate $\% 20$ change \%20intensifies,hold\%204\%25\%20more\%20water\%20vapor. (Accessed on 27/04/2021). 
43. Tukimat, N.N.; Harun, S. Technical note the Projection of Future Rainfall Change Over Kedah, Malaysia with the Statistical Downscaling Model. Malay. J. Civil Engine. 2011, 23, 67-79. DOI:10.11113/MJCE.V23N2.269

44. Tangang, F. T. et al. Climate Change and Variability over Malaysia: Gaps in Science and Research Information. Sains Malays. 2012, 41, 1355-1366.

45. Mayowa, O.O.; Pour, S.H.; Shahid, S.; Mohsenipour, M.; Harun, S.B.; Heryansyah, A.; Ismail, T. Trends in rainfall and rainfallrelated extremes in the east coast of peninsular Malaysia. J. Earth Syst. Sci. 2015, 124, 1609-1622. https://doi.org/10.1007/s12040015-0639-9

46. Loh, J.L.; Tangang, F.; Juneng, L. et al.. Projected rainfall and temperature changes over Malaysia at the end of the 21st century based on PRECIS modelling system. Asia-Pacific J Atmos Sci. 2016, 52, 191-208. https://doi.org/10.1007/s13143-016-0019-7

47. Syafrina, A.H.; Zalina, M.D.; Juneng, L. Historical trend of hourly extreme rainfall in peninsular Malaysia. Theor. Appl. Climatol. 2015, 120: 259-285. DOI: 10.1007/s00704-014-1145-8

48. Hassan, M.A.; Ahmad Farid, M.A.; Shirai, Y.; Ariffin, H.; Othman, M. R.; Samsudin, M.H.; Hasan, M. Y. Oil Palm Biomass Biorefinery for Sustainable Production of Renewable Materials. Biotechnol. J. 2019, 14, 1800394. https://doi.org/10.1002/biot.201800394

49. Khan, N.; Pour, S.H.; Shahid, S.; Ismail, T.; Ahmed, K.; Chung, E.S.; Nawaz, N.; Wang, X. Spatial distribution of secular trends in rainfall indices of Peninsular Malaysia in the presence of long-term persistence. Meteorol. Appl. 2019, 26, 655-670. https://doi.org/10.1002/met.1792

50. Sa'adi, Z.; Shahid, S.; Ismail, T.; Chung, E.S.; Wang, X. J. Trends analysis of rainfall and rainfall extremes in Sarawak, Malaysia using modified Mann-Kendall test. Meteorol. Atmospheric Phys. 2019, 131, 263-277. https://doi.org/10.1007/s00703-017-0564-3

51. Ridwan, W. M., Sapitang, M., Aziz, A., Kushiar, K. F., Ahmed, A. N., \& El-Shafie, A. Rainfall forecasting model using machine learning methods: Case study Terengganu, Malaysia. Ain Shams Eng. J. 2020, 12, 1651-1663. https://doi.org/10.1016/j.asej.2020.09.011

52. Saimi, F. M.; Hamzah, F. M.; Toriman, M.; E.; Jaafar, O.; Tajudin, H. Trend and linearity analysis of meteorological parameters in peninsular Malaysia. Sustainability. 2020, 12, 1-19. https://doi.org/10.3390/su12229533

53. IPCC. Climate Change 2007: The Physical Science Basis. Contribution of Working Group I to the Fourth Assessment Report of the Intergovernmental Panel on Climate Change [Solomon, S.; Qin, D.; Manning, M.; Chen, Z.; Marquis, M.; Averyt, K.B.; Tignor M.; Miller, H. Ed.; Cambridge University Press, Cambridge, United Kingdom and New York, NY, USA, 2007. pp. 1-996

54. Easterling, W.E.; Crosson, P.R.; Roseberg, N.J.; Mckenney M.S.; Katz, L.A.; Lemon, K.M. Agricultural impacts of and responses to climate change in the Missouri-Iowa-Nebraska-Kansas (MINK) region. Clim. Change. 1993, 24, 23-61, 24.

55. Chizari, A.; Zainalabidin, M.; Mad Nasir, S.; Kelly, W.; Kai, S. et al. The Effects of Climate Change Phenomena on Cocoa Production in Malaysia. Int. j. environ. 2017, 2, 2599-2604

56. Rizal M.A.R.; Tsan, F.Y. Rainfall impact on oil palm production in Malaysia. J. Appl. Hortic. 2008, 18, 12 - 19

57. Legros, S.; Mialet-Serra, I.; Caliman, J.P.; Siregar, F.A.; Clément-Vidal, A.; Dingkuhn, M. Phenology and growth adjustments of oil palm (Elaeis guineensis) to photoperiod and climate variability. Ann. Bot., 2009, 104, 1171-1182. https://doi.org/10.1093/aob/mcp214

58. Paterson, R.R.M. Oil palm survival under climate change in Malaysia with future basal stem rot assessments. For. Pathol. 2020 50, 1-8. https://doi.org/10.1111/efp.12641

59. Paterson, R.R.M. Future scenarios for oil palm mortality and infection by Phytophthora palmivora in Colombia, Ecuador and Brazil, extrapolated to Malaysia and Indonesia. Phytoparasitica, 2020a 48, 513-523. https://doi.org/10.1007/s12600-020-00815-6 
60. Kushairi, A.; Loh, S.K.; Azman, I.; Hishamuddin, E.; Ong-Abdullah, M.; Izuddin, Z.B.M.N.; ... Parveez, G.K.A. Oil palm economic performance in Malaysia and R\&D progress in 2017. J. Oil Palm Res. 2018, 30, 163-195. https://doi.org/10.21894/jopr.2018.0030

61. MPOC. Malaysia palm oil industry. Available online: http://mpoc.org.my/malaysian-palm-oil-industry/\#: : :text=In\%202020\%2C\%20Malaysia\%20accounted\%20for,fats\%20in\%20the\%20same\%20year. (Accessed on 04/05/2021) 